\title{
Evaluation of shrimp protein hydrolysate and krill meal supplementation in low fish meal diet for red seabream (Pagrus major)
}

\author{
Buddhi E. Gunathilaka', Sanaz Khosravi², Jaebeom Shin ${ }^{1}$, Jaehyeong Shin ${ }^{1}$, Mikael Herault ${ }^{3}$, \\ Vincent Fournier ${ }^{3}$, Kyeong-Jun Lee ${ }^{1,4, *}$ \\ ${ }^{1}$ Department of Marine Life Sciences, Jeju National University, Jeju 63243, Korea \\ ${ }^{2}$ Department of Marine Bioscience and Technology, Gangneung-Wonju National University, Gangwon 25457, Korea \\ ${ }^{3}$ Research \& Development Aqua Platform, AQUATIV Corporation, ZA du Gohelis, Elven 56250, France \\ ${ }^{4}$ Marine Science Institute, Jeju National University, Jeju 63333, Korea
}

\begin{abstract}
Protein hydrolysates and krill meal (KM) are used as protein sources in aquafeeds. The study was conducted to examine the supplemental effects of shrimp protein hydrolysates (SH) or KM in a high-plant-protein diet for red seabream (Pagrus major). A fish meal (FM)-based diet (40\%) was considered as the high-FM diet (HFM) and a diet containing $25 \%$ FM and soy protein concentrate, in the expense of FM protein from HFM diet, was considered as the low fish meal (LFM) diet. Two other experimental diets (SH and KM) were prepared by including SH and KM into LFM diet at 5\% inclusion levels in exchange of 5\% FM from the LFM diet. A feeding trial was conducted for fifteen weeks using triplicate group of fish (Initial mean body weight, $8.47 \pm 0.05 \mathrm{~g}$ ) for a diet. Growth performance and feed efficiency of fish were significantly enhanced by HFM, KM and SH supplemented diets over those of fish fed LFM diet. Interestingly, these parameters of fish fed SH diet showed better performance than KM and HFM groups. Liver IGF-I expression of fish fed SH diet was comparable to HFM group and higher than KM and LFM diets. Protein digestibility of SH diet was significantly higher than KM, HFM, and LFM diets. Dry matter digestibility of SH diet was comparable to HFM diet and significantly higher than KM and LFM diets. Nitro blue tetrazolium and superoxide dismutase activities of HFM, SH and KM groups were significantly elevated than the LFM group and SH diet increased catalase and glutathione peroxidase activities of fish compared to KM and LFM groups. Hemoglobin level and hematocrit of fish fed SH and KM diets were significantly higher than LFM group. A diet containing 20\% FM with KM is comparable to a HFM diet which contains $40 \%$ FM for red seabream. SH can be used to replace FM from red seabream diet down to $20 \%$ and fish performance can be improved better than a diet containing 40\% FM. Overall, it seems that SH is more effective ingredient in red seabream diet compared to KM.
\end{abstract}

Keywords: Red seabream, Shrimp hydrolysate, Krill meal, Digestibility, IGF-I

\footnotetext{
Received: Nov 28, 2020 Revised: Jan 28, 2021 Accepted: Feb 15, 2021

${ }^{\star}$ Corresponding author: Kyeong-Jun Lee

Department of Marine Life Sciences, Jeju National University, Jeju 63243, Korea

Tel: +82-64-754-3423, Fax: +82-64-756-3493, E-mail: kjlee@jejunu.ac.kr
}

This is an Open Access article distributed under the terms of the Creative Commons Attribution Non-Commercial License (http://creativecommons.org/licenses/by$\mathrm{nc} / 4.0 /$ ) which permits unrestricted non-commercial use, distribution, and reproduction in any medium, provided the original work is properly cited.

Copyright $\odot 2021$ The Korean Society of Fisheries and Aquatic Science 


\section{Introduction}

Fish meal (FM) replacement with alternative protein sources is considered a major research area in aqua feed industry over the last few decades due to limited FM supply and higher demand. Fisheries by-products and other marine protein sources have been used in FM replacement studies as supplements to compensate impaired growth performance caused by FM reduced diets (Khosravi et al., 2015a; Leal et al., 2010; Leduc et al., 2018; Plascencia-Jatomea et al., 2002). As the result, advanced processing technologies have been developed to improve the quality of the by-products (Chalamaiah et al., 2012; Dong et al., 2008).

Shrimp hydrolysates $(\mathrm{SH})$ are produced from shrimp by-product or processing wastes such as shrimp heads, cuticles or tail muscles. In particular, shrimp cephalothorax and exoskeleton contain asthaxanthin and protein those are account for $35 \%-45 \%$ of whole-body weight as inedible wastes (Meyers, 1986; Shahidi and Synowiecki, 1991). Therefore, several methods were exploited to make the by-products edible or valuable. Hydrolysis method was recommended as a successful way to convert by-products into micro nutrients (Bueno-Solano et al., 2009; Cahú et al., 2012; López-Cervantes et al., 2006; Nwanna, 2003). The studies on SH have revealed antioxidant, antihypertensive, antimicrobial and myotropic activities (Huang et al., 2011; Kleekayai et al., 2015; Leduc et al., 2018; Nii et al., 2008). Trace amounts of heavy metals, such as $\mathrm{Hg}, \mathrm{Pb}$ and $\mathrm{Cd}$ were recorded in shrimp by-products while free amino acid (AA) content was $15 \%$ higher than the edible parts of shrimp (Heu et al., 2003). In this regard, $\mathrm{SH}$ has been evaluated in diets for fish and shrimp species, and positive effects were elucidated on growth, immunity, digestibility, palatability and health (Khosravi et al., 2015a, 2015b; Khosravi et al., 2018; Leal et al., 2010; Leduc et al., 2018; Plascencia-Jatomea et al., 2002).

Krill are small crustaceans classified into order Euphausiacea. They are one of the primary food sources for large marine mammals and fishes (Hardy, 2008) and a rich source of marine proteins, omega 3 fatty acids, phospholipids and astaxanthine. Therefore, krill processing by-products are used to produce valuable products, such as krill meal (KM), krill hydrolysates and krill oil (Tilseth \& Høstmark 2014 ; Xie et al., 2019). KM is a palatability enhancer in addition to suitable lipid and mineral source for fish (Goto et al., 2001; Hansen et al., 2010). Therefore, increased feed intake (FI) has been reported in fish species when diets are incorporated with KM (Hatlen et al., 2017;
Yoshitomi et al., 2006). Dietary KM supplementation have been proven to improve growth, feed utilization, health status, diet digestibility and disease resistance of fish (Hansen et al., 2010; Yan et al., 2018). Recently, FM replacement ability of KM was reported by several studies in diets for different fish species including gilthead seabream (Sparus aurata) (Saleh et al., 2018), large yellow croaker (Larimichthys crocea) (Wei et al., 2019), and olive flounder (Paralichthys olivaceus) (Tharaka et al., 2020). $\mathrm{KM}$ was also included as a feed ingredient in FM reduced diets for red seabream (Pagrus major) (Takagi et al., 2001; Kader et al., 2012). Shimizu at al. (1990) reported that feeding behavior of red seabreams was stimulated by dietary KM supplementation. Later, Kader et al. (2010) replaced $60 \%$ of FM protein with soy protein concentrate (SPC) and KM in red seabream diet without compromising feeding behavior, growth or health. Recently, Cho et al. (2018) tested KM as a main protein source in red seabream diet and observed that AA and fatty acid profiles of the fish were improved by KM.

Red seabream is cultured within East Asian region. It was the second largest cultured fish species in Japan (Koshio, 2002) and the third one in Korea (Kim et al., 2012; KOSTAT, 2017). In our previous studies, FM replacement was successful with SH and krill hydrolysates from a high-FM (HFM) diet for red seabream (Bui et al., 2014) and HFM effects were restored in diets containing high proportion of plant protein (Khosravi et al., 2015a). Therefore, this study was conducted to examine the effects of SH or KM in a high-plant-protein diet for red seabream compared to a low-FM (LFM) and HFM diets and, meanwhile, compare the supplemental effects of SH and KM in LFM diets for red seabream.

\section{Materials and Methods}

\section{Experimental diets}

Four diets were formulated to contain $45 \%$ crude protein and $18 \mathrm{~kJ} / \mathrm{g}$ energy (Table 1) by inclusion of SH and KM those were provided by DIANA AQUA (Aquaculture Division of DIANA, Member of SYMRISE Group, Elven, France). The molecular weight distribution, proximate and essential AAs composition of SH and KM were presented in Table 2. A diet prepared to contain 40\% FM was considered as a HFM diet. Another diet was prepared to contain 25\% FM and 21\% SPC, was regarded as the LFM diet. Two other experimental diets ( $\mathrm{SH}$ and $\mathrm{KM}$ ) were prepared by including SH or KM into the LFM diet at 5\% inclusion levels in exchange of 5\% FM. Both SH and KM diets 
contained 50\% of FM compared to the HFM diet. All dry ingredients were thoroughly mixed and, after addition of oil and distilled water, the dough was extruded through a pelletizer machine (SP-50, Gum Gang Engineering, Daegu, Korea) in ideal size dried at $25^{\circ} \mathrm{C}$ for $24 \mathrm{~h}$ and stored at $-20^{\circ} \mathrm{C}$.

\section{Fish and feeding trial}

The feeding trial was conducted in the Marine Science Institute, Jeju National University, Jeju, Korea. All fish were acclimatized for two weeks by feeding a commercial diet. Fish $(8.47 \pm 0.05 \mathrm{~g})$ were randomly selected and distributed among twelve polyvinyl circular tanks (30 fish / tank) of a flow-through system in which water flow tare was maintained at $3 \mathrm{~L} / \mathrm{min}$ and air stones were installed to provide oxygen. Tanks were randomly assigned to three replicates of four dietary treatments. Photoperiod was scheduled for 12:12 h light/dark by fluorescent light. Water temperature was ranged from $22.6{ }^{\circ} \mathrm{C}$ to $25.3{ }^{\circ} \mathrm{C}$ during the feeding trial. Ammonia level and $\mathrm{pH}$ were around $0.04 \mathrm{ppm}$ and 7.3 respectively. Fish in each tank were fed one of the experimental diets twice a day (09:00 and 18:00 h) until satiation for fifteen
Table 1. Formulation and proximate composition of the four experimental diets for red seabream (\%, dry matter basis)

\begin{tabular}{|c|c|c|c|c|}
\hline \multirow[t]{2}{*}{ Ingredient } & \multicolumn{4}{|c|}{ Experimental diets } \\
\hline & HFM & LFM & KM & $\mathrm{SH}$ \\
\hline Fish meal $^{1)}$ & 40.0 & 25.0 & 20.0 & 20.2 \\
\hline Krill meal ${ }^{2)}$ & 0.0 & 0.0 & 5.0 & 0.0 \\
\hline Shrimp hydrolysate ${ }^{2)}$ & 0.0 & 0.0 & 0.0 & 5.0 \\
\hline Soy protein concentrate ${ }^{3)}$ & 9.0 & 21.0 & 21.0 & 21.0 \\
\hline Corn gluten meal & 8.0 & 8.0 & 8.0 & 8.0 \\
\hline Wheat flour & 30.5 & 29.8 & 29.8 & 29.6 \\
\hline Squid liver oil & 4.0 & 5.5 & 5.2 & 5.5 \\
\hline Soybean oil & 4.0 & 4.0 & 4.0 & 4.0 \\
\hline Mineral $\mathrm{mix}^{4)}$ & 1.0 & 1.0 & 1.0 & 1.0 \\
\hline Vitamin $\mathrm{mix}^{5)}$ & 1.0 & 1.0 & 1.0 & 1.0 \\
\hline Starch & 2.0 & 1.5 & 1.8 & 1.5 \\
\hline Choline chloride & 0.5 & 0.5 & 0.5 & 0.5 \\
\hline Lysine & 0.0 & 0.5 & 0.5 & 0.5 \\
\hline Methionine & 0.0 & 0.2 & 0.2 & 0.2 \\
\hline Taurine & 0.0 & 0.5 & 0.5 & 0.5 \\
\hline Di-calcium phosphate & 0.0 & 1.5 & 1.5 & 1.5 \\
\hline \multicolumn{5}{|c|}{ Proximate composition (Analyzed, \%) } \\
\hline Dry matter & 91.1 & 91.2 & 91.0 & 90.6 \\
\hline Crude protein & 46.9 & 47.1 & 48.2 & 47.9 \\
\hline Crude lipid & 14.6 & 14.4 & 14.6 & 14.4 \\
\hline Ash & 9.0 & 8.1 & 7.7 & 8.0 \\
\hline
\end{tabular}

1) Morocco fish meal, $66.5 \%$ crude protein and $10.6 \%$ crude lipid.
2) DIANA AQUA, Aquaculture Division of DIANA, Member of SYMRISE Group, Elven, France.

${ }^{3)} \mathrm{SPC}$, Crop, Korea flavour, Korea. $73.6 \%$ crude protein and 3.2\% crude lipid.

${ }^{4)}$ Mineral premix (g/kg of mixture): $\mathrm{MgSO}_{4} \cdot 7 \mathrm{H}_{2} \mathrm{O}, 80.0 ; \mathrm{NaH}_{2} \mathrm{PO}_{4} \cdot 2 \mathrm{H}_{2} \mathrm{O}, 370.0 ; \mathrm{KCl}, 130.0$; Ferric citrate, 40.0; $\mathrm{ZnSO}_{4} \cdot 7 \mathrm{H}_{2} \mathrm{O}, 20.0$; Ca-lactate, 356.5; $\mathrm{CuCl}, 0.2 ; \mathrm{AlCl}_{3} \cdot 6 \mathrm{H}_{2} \mathrm{O}, 0.15$; $\mathrm{Na}_{2} \mathrm{Se}_{2} \mathrm{O}_{3}, 0.01 ; \mathrm{MnSO}_{4} \cdot \mathrm{H}_{2} \mathrm{O}, 2.0 ; \mathrm{CoCl}_{2} \cdot 6 \mathrm{H}_{2} \mathrm{O}, 1.0$.

${ }^{5)}$ Vitamin premix (g/kg of mixture): L-ascorbic acid, 121.2; DL-a tocopheryl acetate, 18.8; thiamin hydrochloride, 2.7; riboflavin, 9.1; pyridoxine hydrochloride, 1.8; niacin, 36.4; Ca-D-pantothenate, 12.7; myo-inositol, 181.8; D-biotin, 0.27; folic acid, 0.68; p-aminobezoic acid, 18.2 ; menadione, 1.8 ; retinyl acetate, 0.73 ; cholecalficerol, 0.003 ; cyanocobalamin, 0.003 .

HFM, high fish meal; LFM, low fish meal; KM, krill meal; SH, shrimp hydrolysate; SPC, soy protein concentrate.
Table 2. The molecular weight distribution, proximate and essential amino acids composition of shrimp hydrolysate (SH) and krill meal (KM) (from product technical data sheets)

\begin{tabular}{|c|c|c|}
\hline & $\mathrm{SH}^{1)}$ & $\mathrm{KM}^{22}$ \\
\hline \multicolumn{3}{|l|}{ Molecular weight ( $\mathrm{Da}, \%$ wet basis) } \\
\hline$>30,000$ & $<0.1$ & - \\
\hline $20,000-30,000$ & $<0.1$ & - \\
\hline $10,000-20,000$ & $<0.1$ & - \\
\hline $5,000-10,000$ & $<0.5$ & - \\
\hline $1,000-5,000$ & 8 & - \\
\hline $500-1,000$ & 9 & - \\
\hline$<500$ & 83 & - \\
\hline \multicolumn{3}{|l|}{ Proximate composition } \\
\hline Dry matter, DM (\%) & 96.7 & 92.6 \\
\hline Protein (\% DM) & 67.2 & 65 \\
\hline Lipid (\% DM) & 12.2 & 24 \\
\hline Ash (\% DM) & 10.3 & 11.8 \\
\hline Soluble protein (\% total protein) & 94 & 13 \\
\hline Total PUFA (\% fatty acids) & 40 & 23 \\
\hline Total omega 3 (\% fatty acids) & 15 & 20 \\
\hline EPA (\% fatty acids) & 6 & 10 \\
\hline DHA (\% fatty acids) & 6 & 5 \\
\hline \multicolumn{3}{|c|}{ Essential amino acids (products, $\%$ wet basis) } \\
\hline $\operatorname{Arg}$ & 4.1 & 3.8 \\
\hline His & 1.5 & 1.5 \\
\hline Ile & 2.7 & 3.5 \\
\hline Leu & 4.3 & 5.3 \\
\hline Lys & 4.1 & 4.9 \\
\hline Met & 1.3 & 2.1 \\
\hline Phe & 2.9 & 3.1 \\
\hline Thr & 2.4 & 3.0 \\
\hline Val & 3.3 & 3.5 \\
\hline
\end{tabular}

${ }^{1,2)} \mathrm{SH}$ and KM were provided by DIANA AQUA, Aquaculture Division of DIANA, Member of SYMRISE Group, Elven, France. 
weeks. Fish growth was measured in three weeks interval. Fish were fasted for $24 \mathrm{~h}$ prior to weighting to minimize stress. FI was calculated by collecting uneaten feed $30 \mathrm{~min}$ after feeding.

\section{Sample collection and analyses}

All the fish from each tank were counted to determine survival rate and bulk weighed to determine growth performance and feed utilization after fifteen weeks of feeding trial. Then, six fish were randomly selected from each tank and anesthetized with 2-phenoxy ethanol solution (200 ppm) by dipping for few minutes. Three fish were selected to withdraw blood samples with syringes containing heparin to separate plasma samples. Another three fish were selected to withdraw blood samples with non-hepasrinized syringes and the serum was separated after clotting at room temperature. Both plasma and serum were separated after centrifugation at 5,000 $\times \mathrm{g}$ for $10 \mathrm{~min}$ and stored at $-80^{\circ} \mathrm{C}$ for further analyses. Three fish were sampled from each tank to analyze whole-body proximate composition.

Standard analytical procedures (AOAC, 2005) were followed to analyze moisture and ash contents. Crude protein was determined by using a Kjeltec Analyzer Unit 2300 (FOSS analytical, Hilleroed, Denmark). Protocol of Folch et al. (1957) was followed to determine crude lipid levels. Hematocrit was measured by microhematocrit technique (Brown, 1980). Plasma biochemical parameters were determined using a blood analyzer (SLIM, SEAC, Florence, Italy). Nitroblue tetrazolium (NBT) assay was performed to determine respiratory burst activity as described by Anderson and Siwicki (1995). Myeloperoxidase (MPO) activity of serum was measured according to Quade and Roth (1997). Serum superoxide dismutase (SOD) activity was measured using a Kit (19160, Sigma-Aldrich, St. Louis, MO, USA). Catalase and glutathione peroxidase (GPx) activities of serum samples were measured using commercial kits (K773-100 and K762-100, Biovision, Milpitas, CA, USA).

\section{Estimation of apparent digestibility coefficients}

Apparent digestibility coefficients (ADCs) of protein and dry matter (DM) of the diets were determined using a Guelph system. For ADCs, the experimental diets were added with $1 \%$ chromic oxide $\left(\mathrm{Cr}_{2} \mathrm{O}_{3}\right)$ (203068, Sigma-Aldrich) which is an inert indicator. Four groups of red seabream (average body weight: $60 \mathrm{~g}$ ) were distributed into tanks (300 L capacity) at a density of 100 fish per tank and fed with the diets containing chromic oxide. The Guelph system was settled to receive cartridge-filtered seawater at $2 \mathrm{~L} / \mathrm{min}$ flow rate. Fecal samples were collected for 2 weeks. Chromic oxide levels were determined according to Divakaran et al. (2002). ADCs for protein and DM of the diets were calculated according to Tharaka et al. (2020).

\section{Expression levels of liver IGF-I mRNA}

Three fish were selected from each tank and livers were separated. Then, samples were immediately frozen in liquid nitrogen. RNA was isolated using TRIzol Reagent (Sigma-Aldrich) and concentrations were checked at $260 \mathrm{~nm}$ using a spectrophotometer after diluting in $0.1 \mathrm{~mL}$ of RNase free water. After, total RNA $(2.5 \mu \mathrm{g})$ were reverse transcribed to cDNA with a kit (6110A, TaKaRa, Shiga, Japan) and volume up to $0.8 \mathrm{~mL}$ with RNase free water. The expression level of IGF-I gene was analyzed with a Real Time System (TP800 Thermal Cycler Dice ${ }^{\mathrm{TM}}$, TaKaRa, Shiga, Japan) by using a fluorescent agent (TB Green). The $18 \mathrm{~S}$ rRNA gene was used as the housekeeping gene and primers for 18S rRNA gene were designed following a cloned sequence (NCBI Genbank accession no: AB259837). Previously designed primers were used for IGF-I gene (Hossain et al., 2016). The relative expression ratio of the gene was calculated following the described model by Pfaffl (2001): Ratio $=[($ EIGF-I) $\Delta$ GF (control-sample)] / [(Eactin) Ct (control-sample)].

\section{Statistical analysis}

Experimental diets were assigned using a completely randomized design. The differences among groups were identified by one-way analysis of variance (ANOVA) in SPSS version 19.0 (SPSS, Chicago, IL, USA). Then, Tukey's HSD test was used to find differences in mean values $(p<0.05)$. The percentage data were arcsine transformed before the comparisons. All the data are presented as mean of three replicates \pm SD.

\section{Results}

All diets were well accepted and consumed by the fish during the feeding trial. Final body weight, weight gain, specific growth rate, feed conversion ratio (FCR) and protein efficiency ratio (PER) were significantly improved in fish fed diets containing HFM, KM, or SH compared to those of fish fed LFM diet. Interestingly, the parameters were significantly higher in fish fed $\mathrm{SH}$ diet than those of fish fed KM and HFM diets. FI and survival of fish were not significantly affected by the dietary treatments. Liver IGF-I mRNA expression of fish fed SH diet was in line with HFM group and significantly higher compared to that of fish fed KM and LFM diets. KM group showed significantly 
higher expression level compared to LFM group. The lowest expression level was observed in fish fed LFM diet (Table 3).

Table 3. Growth performance, feed utilization and liver IGF-I mRNA expression of red seabream fed the four experimental diets for 15 weeks.

\begin{tabular}{lllll}
\hline & \multicolumn{3}{l}{ Experimental diets } \\
\cline { 2 - 5 } & HFM & LFM & KM & SH \\
\hline FBW (g) & $65 \pm 2.55^{\mathrm{b}}$ & $52.9 \pm 1.68^{\mathrm{c}}$ & $63.2 \pm 3.51^{\mathrm{b}}$ & $76.3 \pm 4.79^{\mathrm{a}}$ \\
$\mathrm{WG}^{1)}(\%)$ & $666 \pm 29.4^{\mathrm{ab}}$ & $520 \pm 15.6^{\mathrm{c}}$ & $649 \pm 47.9^{\mathrm{ab}}$ & $810 \pm 60.7^{\mathrm{a}}$ \\
$\mathrm{FI}^{2)}$ & $91.3 \pm 3.94$ & $93.1 \pm 0.91$ & $97.6 \pm 5.48$ & $95.1 \pm 6.46$ \\
$\mathrm{FCR}^{3)}$ & $1.60 \pm 0.08^{\mathrm{bc}}$ & $2.01 \pm 0.05^{\mathrm{a}}$ & $1.74 \pm 0.14^{\mathrm{b}}$ & $1.51 \pm 0.05^{\mathrm{c}}$ \\
$\mathrm{PER}^{4)}$ & $1.33 \pm 0.07^{\mathrm{ab}}$ & $1.06 \pm 0.03^{\mathrm{c}}$ & $1.19 \pm 0.09^{\mathrm{b}}$ & $1.39 \pm 0.05^{\mathrm{a}}$ \\
$\mathrm{SGR}^{5)}(\%)$ & $1.94 \pm 0.04^{\mathrm{b}}$ & $1.74 \pm 0.02^{\mathrm{c}}$ & $1.92 \pm 0.06^{\mathrm{b}}$ & $2.10 \pm 0.06^{\mathrm{a}}$ \\
$\mathrm{IGF-I}^{(6)}$ & $1.00 \pm 0.00^{\mathrm{a}}$ & $0.30 \pm 0.05^{\mathrm{c}}$ & $0.82 \pm 0.07^{\mathrm{b}}$ & $1.12 \pm 0.07^{\mathrm{a}}$ \\
Survival (\%) & $90.0 \pm 5.77$ & $84.4 \pm 1.92$ & $84.4 \pm 5.09$ & $90.0 \pm 3.33$ \\
\hline
\end{tabular}

Values are mean of triplicate groups and presented as mean \pm SD.

Values with different superscripts in the same row are significantly different $(p<0.05)$.

The lack of superscript letter indicates no significant differences among treatments.

${ }^{1)}$ Weight gain $=[($ final body weight - initial body weight $) /$ initial body weight $] \times 100$.

2) Feed intake ( $\mathrm{g} /$ fish) = dry feed consumed (g) / fish

${ }^{3)}$ Feed conversion ratio $=$ dry feed fed/wet weight gain .

4) Protein efficiency ratio $=$ fish weight gain $(g) /$ protein .

${ }^{5)}$ Specific growth rate $=\ln$ (final weight in grams) $-\ln$ (initial weight in grams) $\times 100$.

${ }^{6}$ ) Liver insulin-like growth factors I (relative expression of mRNA).

HFM, high fish meal; LFM, low fish meal; KM, krill meal; SH, shrimp hydrolysate; FBW, final

body weight.
$\mathrm{DM}$ and protein digestibility of diets were significantly enhanced by inclusion of SH and KM (Fig. 1). Protein digestibility of SH diet was significantly higher than KM, HFM, and LFM diets. Protein digestibility of KM and HFM diets were significantly higher than LFM diet. DM digestibility of SH diet was significantly higher than KM and LFM diets although values observed in $\mathrm{SH}$ and $\mathrm{KM}$ diets were comparable to HFM diet. The lowest protein and DM digestibility were found in LFM diet.

The results of innate immune and antioxidant enzyme analyses are shown in Table 4. Innate immune responses of fish fed $\mathrm{SH}$ diet were significantly enhanced compared to those of fish fed the LFM diet. Even though SH group showed the most improved innate immunity, NBT and SOD activities of HFM and KM groups were significantly elevated than the LFM group. However, catalase and GPx activities of KM group were comparable to LFM group. MPO activity was not significantly affected by diets.

The results of blood parameters are shown in Table 4. Hemoglobin level and hematocrit of fish fed $\mathrm{SH}$ and $\mathrm{KM}$ diets were significantly higher than that of fish fed LFM diet. However, cholesterol, glucose and total protein levels of fish were not significantly affected by the diets. No significant differences were observed in whole-body composition of fish (Table 5).

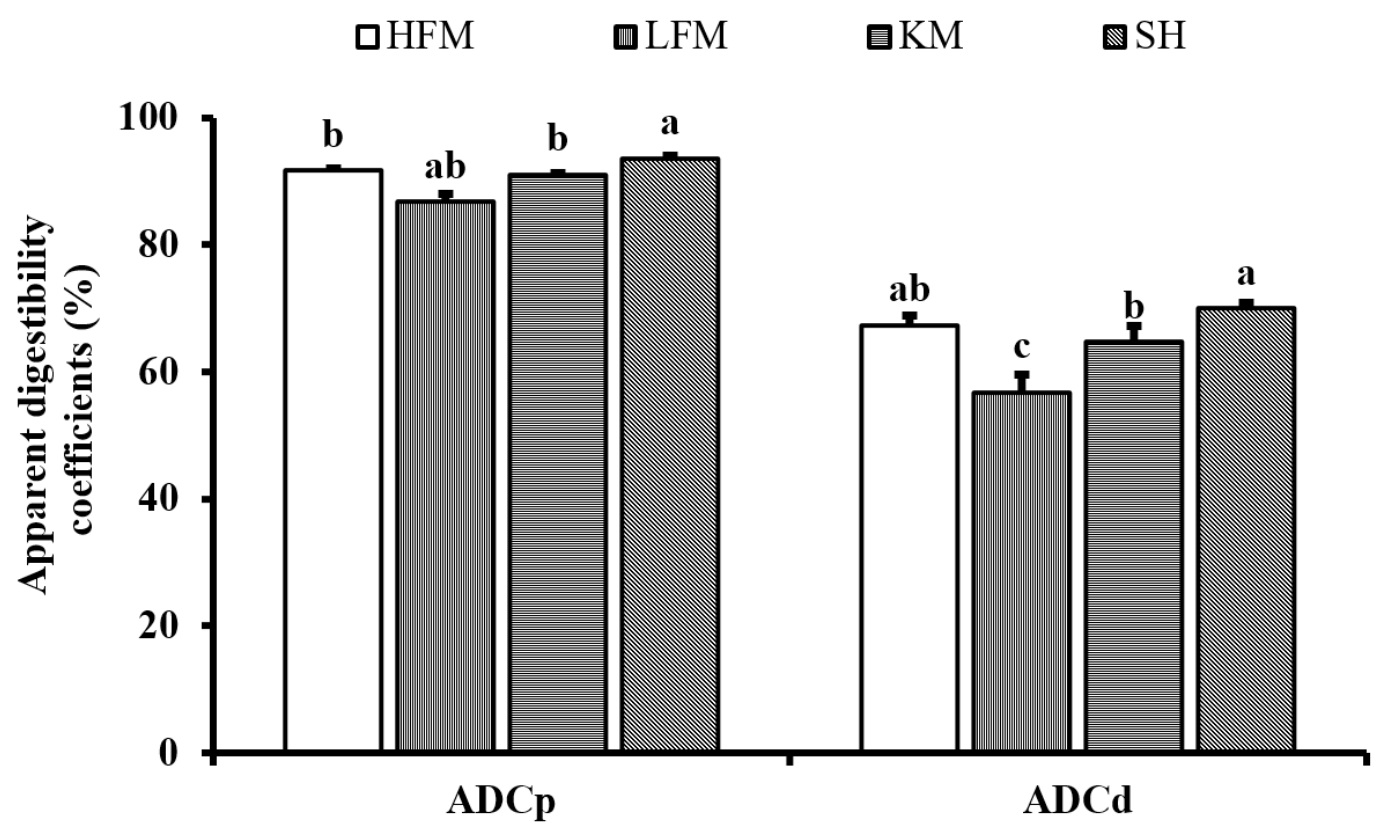

Fig. 1. Apparent digestibility coefficients $(\%, A D C)$ for protein $(A D C p)$ and dry matter (ADCd) of the experimental diets for red seabream. HFM, high fish meal; LFM, low fish meal; KM, krill meal; $\mathrm{SH}$, shrimp hydrolysate. 
Table 4. Blood immunological, hematological and biochemical parameters of red seabream fed the four experimental diets for 15 weeks

\begin{tabular}{lllll}
\hline & HFM & LFM & KM & SH \\
\hline NBT $^{1)}$ & $0.95 \pm 0.07^{\mathrm{ab}}$ & $0.71 \pm 0.04^{\mathrm{c}}$ & $0.84 \pm 0.07^{\mathrm{b}}$ & $1.02 \pm 0.06^{\mathrm{a}}$ \\
$\mathrm{MPO}^{2)}$ & $1.66 \pm 0.13$ & $1.36 \pm 0.11$ & $1.76 \pm 0.44$ & $1.81 \pm 0.09$ \\
$\mathrm{SOD}^{3)}$ & $74.8 \pm 0.3^{\mathrm{ab}}$ & $63.3 \pm 2.7^{\mathrm{c}}$ & $74.6 \pm 2.2^{\mathrm{b}}$ & $81.6 \pm 4.1^{\mathrm{a}}$ \\
$\mathrm{GPx}^{4)}$ & $109 \pm 17^{\mathrm{a}}$ & $75.9 \pm 7.9^{\mathrm{b}}$ & $95.5 \pm 20^{\mathrm{ab}}$ & $116 \pm 8.8^{\mathrm{a}}$ \\
Catalase $^{5)}$ & $1.35 \pm 0.09^{\mathrm{ab}}$ & $1.05 \pm 0.09^{\mathrm{c}}$ & $1.19 \pm 0.07^{\mathrm{bc}}$ & $1.41 \pm 0.14^{\mathrm{a}}$ \\
Hematocrit (\%) & $37.6 \pm 4.0^{\mathrm{ab}}$ & $32.7 \pm 0.9^{\mathrm{b}}$ & $37.6 \pm 2.8^{\mathrm{a}}$ & $35.8 \pm 1.3^{\mathrm{a}}$ \\
Hemoglobin (g/dL) $^{\mathrm{ab}}$ & $5.89 \pm 0.2^{\mathrm{a}}$ & $4.86 \pm 1.06^{\mathrm{b}}$ & $6.96 \pm 0.77^{\mathrm{a}}$ & $6.58 \pm 0.27^{\mathrm{a}}$ \\
Total protein (g/dL) & $1.87 \pm 0.15$ & $1.43 \pm 0.04$ & $1.68 \pm 0.47$ & $1.94 \pm 0.09$ \\
Glucose (mg/dL) $_{\text {Total cholesterol }}$ & $227.6 \pm 1.0$ & $55.5 \pm 1.6$ & $55.8 \pm 3.8$ & $57.6 \pm 3.0$ \\
(mg/dL) $^{2}$ & $210 \pm 6.0$ & $217 \pm 13$ & $231 \pm 13$ \\
\hline
\end{tabular}

Values are mean of triplicate groups and presented as mean \pm SD.

Values with different superscripts in the same row are significantly different $(p<0.05)$.

The lack of superscript letter indicates no significant differences among treatments.

${ }^{1)}$ Nitro blue tetrazolium activity (OD)

${ }^{2)}$ Myeloperoxidase activity (OD).

${ }^{3)}$ Superoxide dismutase (\% inhibition).

4) Glutathione peroxidase activity $(\mathrm{mU} / \mathrm{mL})$

${ }^{5)}$ Catalase activity $(\mathrm{mU} / \mathrm{mL})$

HFM, high fish meal; LFM, low fish meal; KM, krill meal; SH, shrimp hydrolysate.

Table 5. Whole-body composition of red seabream fed the four experimental diets for 15 weeks (\%, DM)

\begin{tabular}{lllll}
\hline & HFM & LFM & KM & SH \\
\hline Dry matter & $30.0 \pm 0.41$ & $32.7 \pm 1.20$ & $32.9 \pm 0.60$ & $33.1 \pm 1.59$ \\
Protein & $53.6 \pm 0.4$ & $51.8 \pm 0.3$ & $53.6 \pm 1.4$ & $54.0 \pm 0.2$ \\
Lipid & $34.1 \pm 2.5$ & $32.8 \pm 2.5$ & $33.4 \pm 2.1$ & $33.8 \pm 0.8$ \\
Ash & $13.9 \pm 1.0$ & $11.4 \pm 0.6$ & $13.7 \pm 1.4$ & $13.8 \pm 0.8$ \\
\hline
\end{tabular}

Values are mean of triplicate groups and presented as mean $\pm \mathrm{SD}$.

HFM, high fish meal; LFM, low fish meal; KM, krill meal; SH, shrimp hydrolysate.

\section{Discussion}

A LFM diet containing SH improved fish growth and exerted even better performance than the HFM group. Also, growth performance of fish fed KM diet was comparable to HFM group. In our previous studies, growth performance of red seabream was improved by supplementation of $5 \% \mathrm{SH}$ compared to a HFM diet (Bui et al., 2014). HFM effects were shown by red seabream fed a SPC based LFM diet containing SH (Khosravi et al., 2015a). FI of fish was not significantly influenced by the experimental diets in the present study. Therefore, increased fish growth by SH or KM supplementation might be due to the nutritional quality of diets which was represented by improved FCR and PER compared to the LFM group. KM and SH have balanced essential AAs and fatty acids for fishes. Soluble protein level is high in SH which contains high level of low molecular weight peptides (Table 2). Many active peptides, known as growth promoter in fish, are found in these molecular ranges (Chalamaiah et al., 2012). Also, crude lipid level and omega-3 fatty acids and EPA , are high in KM. SH and KM contain astaxanthin which is a growth stimulator of fish (Cheng et al., 2018; Kalinowski et al., 2011; Li et al., 2014; Li et al., 2018; Lim et al., 2018; Xie et al., 2017). Therefore, these compounds might be involved in restoring HFM effects by SH or KM supplementation into the LFM diet. Teshima et al. (2004) reported that dietary supplementation of low molecular weight peptides enhances the growth performance of red seabream. Kondo et al. (2017) demonstrated that feed conversion and expression of digestive enzymes of red seabream can be improved by dietary protein hydrolysate supplementation. Supportively, low molecular compounds and peptides which are generated during the process of hydrolysis might be associated with the enhanced growth performance of fish fed diets containing SH compared to the KM group.

IGF-I is identified as a mitogenic polypeptide that can mediate somatic growth-stimulatory effects of growth hormone. It is secreted by the liver and transported to other tissues in vertebrates (Laron, 2001; Merimee \& Laron, 1996). In the same way, IGF-I in teleost is regulated by growth hormone and secretion of hepatic IGF-I in a dose-dependent manner (Shamblott et al., 1995). IGF-I plays an important role to develop nervous system and muscle during the larval stage of Chilean flounder (Paralichthys adspersus) (Escobar, 2011). Furthermore, McCormick (1996) demonstrated that this gene might be involved in osmoregulation of Atlantic salmon (Salmo salar). In the present study, relative expression levels of liver IGF-I mRNA of LFM fish group did not reach to those of HFM fish group. However, KM supplementation resulted in upregulated expression level of the LFM group and dietary SH supplementation restored the HFM effects. Bjørndal et al. (2012) observed that dietary krill powder can upregulate the expression of animal genes. Zheng et al. (2012) found that liver IGF-I expression of Japanese flounder (Paralichthys olivaceus) was significantly increased by replacing $16 \%$ FM with protein hydrolysates. The present results along with the previous ones indicate that the $\mathrm{SH}$, as a hydrolysate, could recover a decreased IGF-I expression of fish fed a diet containing high-plant protein sources even though the exact mechanism was not clearly verified. According to Metón et al. 
(2000), IGF-I expression of gilthead seabream can be changed after feeding. They observed normalized expression about 16 $\mathrm{h}$ after the last feeding. Therefore, IGF-I expression might not be changed with sample collection time in the present study because fish were fasted for $24 \mathrm{~h}$ before sampling. Plasma IGF-I level was also found to have a correlation with the protein contents of isocaloric diets (Moriyama et al., 2000). SH and KM used for this study contain almost similar level of AAs and proteins. Whereas, soluble protein level in $\mathrm{SH}$ was higher compared to $\mathrm{KM}$ (Table 2). Therefore, high levels of soluble protein in $\mathrm{SH}$ might explain the reason for the increased IGF-I expression.

In our previous studies, $\mathrm{SH}$ supplementation improved protein and DM digestibility of red seabream compared to a HFM diet (Bui et al., 2014). Digestibility of red seabream diet is dependent on several factors such as feeding rate (Takii et al., 1997), photoperiod (Biswas et al., 2005) and stocking density (Biswas et al., 2007). Dossou et al. (2018) reported that FM could be substituted up to $25 \%$ with fermented rapeseed meal without compromising digestibility of protein in red seabream diet. However, LFM diet showed significantly lower protein digestibility in the present study indicating that SPC was not capable to replace FM in red seabream diet down to $25 \%$ without compromising protein digestibility. SH and KM groups restored the HFM effects by increasing diet digestibility. Kader and Koshio (2012) improved diet digestibility by incorporating $20 \%$ of FM with fermented soybean meal and fish soluble in red seabream diet. Protein and AA digestibility of red seabream vary with protein sources in diet (Yamamoto et al., 1998). Therefore, in line with these findings, it can be assumed that proper level of SH was included in a LFM diet for red seabream possessing an ability to enhance protein and DM digestibility of the diet. KM supplementation was reported increased digestibility of no-FM diet for Nile tilapia (Oreochromis niloticus) (Gaber, 2005). Tibbetts et al. (2006) observed that protein digestibility of Atlantic cod (Gadus morhua) was improved by KM supplementation. However, in our study, protein and DM digestibility were higher in SH diet than that of KM diet. Nutritional quality of SH, especially higher levels of low molecular weight compounds, seems to be the main reason for the improved protein digestibility of diet compared to KM or HFM diets.

Innate immune system is considered as the core defense mechanism found in fish for combating infections (Magnadóttir, 2006). In the present study, NBT activity and antioxidant enzymes such as serum catalase, SOD and GPx activities were significantly enhanced by dietary inclusion of SH or KM in a LFM diet. SH supplementation resulted in even higher performance than HFM group. According to our previous studies, innate immunity of red seabream was boosted by $\mathrm{SH}$ incorporation into a LFM diet restoring the positive HFM effects (Khosravi et al., 2015a). Innate immune system of olive flounder was also stimulated by dietary SH (Gunathilaka et al., 2020; Khoshravi et al., 2018) and KM (Tharaka et al., 2020) supplementation. Innate immunity of Japanese sea bass (Lateolabrax japonicas) and Atlantic halibut (Hippoglossus hippoglossus) was enhanced by dietary supplementation of hydrolysates from Pollock by-product (Hermannsdottir et al., 2009; Liang et al., 2006). Siddik et al. (2019) reported that immune responses of Asian seabass (Lates calcarifer) can be improved by tuna hydrolysates supplementation in diets. Immunostimulatory effects of different hydrolysates products have been revealed over past decade (Chalamaiah et al., 2015; Chalamaiah et al., 2018; Huang et al., 2014; Karnjanapratum et al., 2016). Dietary AAs were reported to boost immunity and antioxidant enzyme activities of fishes (Machado et al., 2015; Pohlenz et al., 2012). Both SH and KM contain high levels of AAs although the $\mathrm{SH}$ contained high soluble nitrogen level and low-molecular compounds than KM. Therefore, $\mathrm{SH}$ might contain nucleotides and peptides among low molecular weight compounds. Both nucleotides and peptides were identified as immune modulators in animals including fishes (Cederlund et al., 2011; Chiou et al., 2006; de Cruz et al., 2020; Harris and Bird, 2000; Rajanbabu and Chen, 2011; Valero et al., 2020). Therefore, innate immunity of red seabream might be boosted more efficiently by dietary SH supplementation compared to KM which was not hydrolyzed. Evidences from previous studies elucidated that chitin present in KM have ability to improve immunity of fish (Ringø et al., 2012). Several studies reported that chitin improve disease resistance of fish along with the immunity (Ringø et al., 2012). Improved immunity is properly reflected by a disease challenge against virulent pathogen in red seabream aquaculture. Therefore, we suggest to conduct immune based challenge test in future experiments to illustrate immune boosting effects of LFM diets containing SH and KM.

Blood hematocrit and hemoglobin level of fish significantly improved by dietary KM and SH supplementation compared to LFM group. Olsen et al. (2006) reported that dietary KM supplementation had no adverse effects on hematocrit, hemoglobin or red blood cell count of Atlantic salmon. Also, Silva-Carrillo et al. (2012) replaced FM from juvenile spotted rose snapper (Lutjanus guttatus) diet with soybean meal up to $60 \%$ without adverse effects on hematocrit and hemoglobin level when diets 
were supplemented with KM and Squid meal. Khosravi et al. (2015a) observed increment in blood hemoglobin and hematocrit by dietary SH supplementation. High level of plant protein in diets causes to reduce hemoglobin level and hematocrit of fish (Haghbayan et al., 2015). Accordingly, in our study, blood hemoglobin level and hematocrit were reduced by LFM diet due to high level of SPC and increased by KM and SH to reach HFM effects. The improved nutritional status as represented by growth performance, feed utilization and diet digestibility of $\mathrm{SH}$ and $\mathrm{KM}$ group might be connected with restored hemoglobin and hematocrit levels.

\section{Conclusion}

The results observed by this study provide evidences to prove that the $20 \%$ of FM inclusion in red seabream diet with $\mathrm{KM}$ is comparable to a HFM diet which contain 40\% FM. Also, compared to KM, SH can be used to replace FM from red seabream diet down to $20 \%$ and fish performance can be maintained better than a diet containing 40\% FM. Therefore, inclusion of $\mathrm{SH}$ in LFM diet is more effective than KM to improve growth, digestibility and immunity of red seabream.

\section{Competing interests}

No potential conflict of interest relevant to this article was reported.

\section{Funding sources}

This study was supported by AQUATIV (Aquaculture Division of DIANA, Member of SYMRISE Group), Elven, France and Basic Science Research Program through the National Research Foundation of Korea (NRF) funded by the Ministry of Education (2019R1A6A1A03033553).

\section{Acknowledgements}

Not applicable.

\section{Availability of data and materials}

Upon reasonable request, the datasets of this study can be available from the corresponding author.

\section{Ethics approval and consent to participate}

Experimental protocols followed the guidelines of the Animal Care and Use Committee of Jeju National University.

\section{ORCID}

Kyeong-Jun Lee https://orcid.org/0000-0003-0268-578X

Buddhi E. Gunathilaka https://orcid.org/0000-0002-0654-9980

\section{References}

Anderson DP, Siwicki AK. Basic hematology and serology for fish health programs. In: Shariff M, Arthur JR, Subasinghe RP, editors. Diseases in Asian aquaculture II. Selangor, Malaysia: Fish Health Section, Asian Fisheries Society; 1995. p. 185-202.

AOAC [Association of Official Analytical Chemists] International. Official methods of analysis of AOAC International. 18th ed. Gaithersburg, MD: AOAC International; 2005.

Biswas AK, Seoka M, Inoue Y, Takii K, Kumai H. Photoperiod influences the growth, food intake, feed efficiency and digestibility of red sea bream (Pagrus major). Aquaculture. 2005;250:666-73.

Biswas AK, Seoka M, Takii K, Kumai H. Comparison of apparent digestibility coefficient among replicates and different stocking density in red sea bream Pagrus major. Fish Sci. 2007;73:19-26.

Bjørndal B, Vik R, Brattelid T, Vigerust NF, Burri L, Bohov P, et al. Krill powder increases liver lipid catabolism and reduces glucose mobilization in tumor necrosis factor-alpha transgenic mice fed a high-fat diet. Metabolism. 2012;61:1461-72.

Brown BA. Routine hematology procedures. In: Brown BA, editor. Hematology, principles and procedures. Philadelphia, PA: Leo and Febiger; 1980. p. 71-112.

Bueno-Solano C, López-Cervantes J, Campas-Baypoli ON, Lauterio-García R, Adan-Bante NP, Sánchez-Machado DI. Chemical and biological characteristics of protein hydrolysates from fermented shrimp by-products. Food Chem. 2009;112:671-75.

Bui HTD, Khosravi S, Fournier V, Herault M, Lee KJ. Growth performance, feed utilization, innate immunity, digestibility and disease resistance of juvenile red seabream (Pagrus major) fed diets supplemented with protein hydrolysates. Aquaculture. 2014;418-419:11-16.

Cahú TB, Santos SD, Mendes A, Córdula CR, Chavante SF, Carvalho LB, et al. Recovery of protein, chitin, carotenoids and glycosaminoglycans from Pacific white shrimp (Litopenaeus vannamei) processing waste. Process Biochem. 2012;47:570-77.

Cederlund A, Gudmundsson GH, Agerberth B. Antimi- 
crobial peptides important in innate immunity. FEBS J. 2011;278:3942-51

Chalamaiah M, Dinesh Kumar B, Hemalatha R, Jyothirmayi T. Fish protein hydrolysates: proximate composition, amino acid composition, antioxidant activities and applications: a review. Food Chem. 2012;135:3020-38.

Chalamaiah M, Hemalatha R, Jyothirmayi T, Diwan PV, Bhaskarachary K, Vajreswari A, et al. Chemical composition and immunomodulatory effects of enzymatic protein hydrolysates from common carp (Cyprinus carpio) egg. Nutrition. 2015;31:388-98.

Chalamaiah M, Yu W, Wu J. Immunomodulatory and anticancer protein hydrolysates (peptides) from food proteins: a review. Food Chem. 2018;245:205-22.

Cheng CH, Guo ZX, Ye CX, Wang AL. Effect of dietary astaxanthin on the growth performance, non-specific immunity, and antioxidant capacity of pufferfish (Takifugu obscurus) under high temperature stress. Fish Physiol. Biochem. 2018;44:209-18.

Chiou PP, Khoo J, Bols NC, Douglas S, Chen TT. Effects of linear cationic $\alpha$-helical antimicrobial peptides on immune-relevant genes in trout macrophages. Dev Comp Immunol. 2006;30:797-806.

Cho JH, Haga Y, Masuda R, Satoh S. Periodic changes in the growth performance and biochemical composition of juvenile red sea bream Pagrus major fed non-heated and heated squid and krill meal-based diets. Fish Sci. 2018;84:699-713.

de Cruz CR, Yamamoto FY, Ju M, Chen K, Velasquez A, Gatlin DM. Efficacy of purified nucleotide supplements on the growth performance and immunity of hybrid striped bass Morone chrysops $\times$ Morone saxatilis. Fish Shellfish Immunol. 2020;98:868-74.

Divakaran S, Obaldo LG, Forster IP. Note on the methods for determination of chromic oxide in shrimp feeds. J Agric Food Chem. 2002;50:464-67.

Dong S, Zeng M, Wang D, Liu Z, Zhao Y, Yang H. Antioxidant and biochemical properties of protein hydrolysates prepared from Silver carp (Hypophthalmichthys molitrix). Food Chem. 2008;107:1485-93.

Dossou S, Koshio S, Ishikawa M, Yokoyama S, Dawood MAO, El Basuini MF, et al. Growth performance, blood health, antioxidant status and immune response in red sea bream (Pagrus major) fed Aspergillus oryzae fermented rapeseed meal (RM-Koji). Fish Shellfish Immunol. 2018;75:253-62.

Escobar S, Fuentes EN, Poblete E, Valdés JA, Safian D, Reyes
AE, et al. Molecular cloning of IGF-1 and IGF-1 receptor and their expression pattern in the Chilean flounder (Paralichthys adspersus). Comp Biochem Physiol B Biochem Mol Biol. 2011;159:140-147.

Folch J, Lees M, Sloane Stanley GH. A simple method for the isolation and purification of total lipides from animal tissues. J Biol Chem. 1957;226:497-509.

Gaber MMA. The effect of different levels of krill meal supplementation of soybean-based diets on feed intake, digestibility, and chemical composition of Juvenile Nile tilapia Oreochromis niloticus, L. J World Aquac Soc. 2007;36:346-53.

Goto T, Takagi S, Ichiki T, Sakai T, Endo M, Yoshida T, et al. Studies on the green liver in cultured red sea bream fed low level and non-fish meal diets: relationship between hepatic taurine and biliverdin levels. Fish Sci. 2001;67:58-63.

Gunathilaka BE, Khosravi S, Herault M, Fournier V, Lee C, Jeong JB. Evaluation of shrimp or tilapia protein hydrolysate at graded dosages in low fish meal diet for olive flounder (Paralichthys olivaceus). Aquac Nutr. 2020;26:1592-603.

Haghbayan S, Shamsaie Mehrgan M. The effect of replacing fish meal in the diet with enzyme-treated soybean meal (HP310) on growth and body composition of rainbow trout fry. Molecules. 2015;20:21058-66.

Hansen JØ, Penn M, Øverland M, Shearer KD, Krogdahl Å, Mydland LT, et al. High inclusion of partially deshelled and whole krill meals in diets for Atlantic salmon (Salmo salar). Aquaculture. 2010;310:164-72.

Hardy RW. Alternative marine sources of fish feed and farmed fish quality. In: Lie $\varnothing$, editor. Improving farmed fish quality and safety. Cambridge, MA: Woodhead; 2008. p. 328-42.

Harris J, Bird DJ. Modulation of the fish immune system by hormones. Vet Immunol Immunopathol. 2000;77:163-76.

Hatlen B, Berge K, Nordrum S, Johnsen K, Kolstad K, Mørkøre T. The effect of low inclusion levels of Antarctic krill (Euphausia superba) meal on growth performance, apparent digestibility and slaughter quality of Atlantic salmon (Salmo salar). Aquac Nutr. 2017;23:721-9.

Hermannsdottir R, Johannsdottir J, Smaradottir H, Sigurgisladottir S, Gudmundsdottir BK, Bjornsdottir R. Analysis of effects induced by a pollock protein hydrolysate on early development, innate immunity and the bacterial community structure of first feeding of Atlantic halibut (Hippoglossus hippoglossus L.) larvae. Fish Shellfish Immunol. 2009;27:595-602.

Heu MS, Kim JS, Shahidi F. Components and nutritional 
quality of shrimp processing by-products. Food Chem. 2003;82:235-42.

Hossain MS, Koshio S, Ishikawa M, Yokoyama S, Sony NM, Dawood MAO. Efficacy of nucleotide related products on growth, blood chemistry, oxidative stress and growth factor gene expression of juvenile red sea bream, Pagrus major. Aquaculture. 2016;464:8-16.

Huang D, Yang L, Wang C, Ma S, Cui L, Huang S, et al. Immunostimulatory activity of protein hydrolysate from oviductus ranae on macrophage in vitro. Evid-Based Complement Alternat Med. 2014;1-11.

Huang GR, Zhao J, Jiang JX. Effect of defatting and enzyme type on antioxidative activity of shrimp processing byproducts hydrolysate. Food Sci Biotechnol. 2011;20:651-7.

Kader MA, Bulbul M, Koshio S, Ishikawa M, Yokoyama S, Nguyen BT, et al. Effect of complete replacement of fishmeal by dehulled soybean meal with crude attractants supplementation in diets for red sea bream, Pagrus major. Aquaculture. 2012;350:109-16.

Kader MA, Koshio S. Effect of composite mixture of seafood by-products and soybean proteins in replacement of fishmeal on the performance of red sea bream, Pagrus major. Aquaculture. 2012;368:95-102.

Kader MA, Koshio S, Ishikawa M, Yokoyama S, Bulbul M. Supplemental effects of some crude ingredients in improving nutritive values of low fishmeal diets for red sea bream, Pagrus major. Aquaculture. 2010;308:136-44.

Kalinowski CT, Robaina LE, Izquierdo MS. Effect of dietary astaxanthin on the growth performance, lipid composition and post-mortem skin colouration of red porgy Pagrus pagrus. Aquac Int. 2011;19:811-23.

Karnjanapratum S, O'Callaghan YC, Benjakul S, O’Brien N. Antioxidant, immunomodulatory and antiproliferative effects of gelatin hydrolysate from unicorn leatherjacket skin. J Sci Food Agric. 2016;96:3220-6.

Khosravi S, Bui HTD, Herault M, Fournier V, Kim KD, Lee BJ, et al. Supplementation of protein hydrolysates to a low-fishmeal diet improves growth and health status of juvenile olive flounder, Paralichthys olivaceus. J World Aquac Soc. 2018;49:897-911.

Khosravi S, Bui HTD, Rahimnejad S, Herault M, Fournier V, Jeong JB. Effect of dietary hydrolysate supplementation on growth performance, non-specific immune response and disease resistance of olive flounder (Paralichthys olivaceus) challenged with Edwardsiella tarda. Aquac Nutr. 2015b;21:321-31.

Khosravi S, Rahimnejad S, Herault M, Fournier V, Lee CR, Bui HTD, et al. Effects of protein hydrolysates supplementation in low fish meal diets on growth performance, innate immunity and disease resistance of red sea bream Pagrus major. Fish Shellfish Immunol. 2015a;45:858-68.

Kim DH, Lipton D, Choi JY. Analyzing the economic performance of the red sea bream Pagrus major offshore aquaculture production system in Korea. Fish Sci. 2012;78:1337-42.

Kleekayai T, Harnedy PA, O’Keeffe MB, Poyarkov AA, CunhaNeves A, Suntornsuk W. Extraction of antioxidant and ACE inhibitory peptides from Thai traditional fermented shrimp pastes. Food Chem. 2015;176:441-7.

Kondo F, Ohta T, Iwai T, Ido A, Miura C, Miura T. Effect of the squid viscera hydrolysate on growth performance and digestion in the red sea bream Pagrus major. Fish Physiol Biochem. 2017;43:1543-55.

Koshio S. Red sea bream, Pagrus major. In: Webster CD, Lim $\mathrm{CE}$, editors. Nutrient requirements and feeding of finfish for aquaculture. New York, NY: CABI; 2002. p. 51-63.

KOSTAT [Statistics Korea]. Preliminary results of the survey on the status of fish culture in 2016 [Internet]. 2017 [cited 2020 Mar 26]. http://kostat.go.kr/assist/synap/preview/skin/doc. html?fn=synapview360318_1\&rs=/assist/synap/preview

Laron Z. Insulin-like growth factor 1 (IGF-1): a growth hormone. J Clin Pathol Mol Pathol. 2001;54:311-6.

Leal ALG, de Castro PF, de Lima JPV, de Souza Correia E, de Souza Bezerra R. Use of shrimp protein hydrolysate in Nile tilapia (Oreochromis niloticus, L.) feeds. Aquac Int. 2010;18:635-46.

Leduc A, Zatylny-Gaudin C, Robert M, Corre E, Corguille GL, Castel $\mathrm{H}$, et al. Dietary aquaculture by-product hydrolysates: impact on the transcriptomic response of the intestinal mucosa of European seabass (Dicentrarchus labrax) fed low fish meal diets. BMC Genomics. 2018;19: 396.

Li F, Huang S, Lu X, Wang J, Lin M, An Y. Effects of dietary supplementation with algal astaxanthin on growth, pigmentation, and antioxidant capacity of the blood parrot (Cichlasoma citrinellum $\times$ Cichlasoma synspilum ). J Oceanol Limnol. 2018;36:1851-9.

Li M, Wu W, Zhou P, Xie F, Zhou Q, Mai K. Comparison effect of dietary astaxanthin and Haematococcus pluvialis on growth performance, antioxidant status and immune response of large yellow croaker Pseudosciaena crocea. Aquaculture. 2014;434:227-32. 
Liang M, Wang J, Chang Q, Mai K. Effects of different levels of fish protein hydrolysate in the diet on the nonspecific immunity of Japanese sea bass, Lateolabrax japonicus $(\mathrm{Cu}-$ vieret Valenciennes, 1828). Aquac Res. 2006;37:102-6.

Lim KC, Yusoff FM, Shariff M, Kamarudin MS. Astaxanthin as feed supplement in aquatic animals. Rev Aquac. 2018;10:738-73.

López-Cervantes J, Sánchez-Machado DI, Ríos-Vázquez NJ. High-performance liquid chromatography method for the simultaneous quantification of retinol, a-tocopherol, and cholesterol in shrimp waste hydrolysate. J Chromatogr A. 2006;1105:135-9.

Machado M, Azeredo R, Díaz-Rosales P, Afonso A, Peres H, Oliva-Teles A. Dietary tryptophan and methionine as modulators of European seabass (Dicentrarchus labrax) immune status and inflammatory response. Fish Shellfish Immunol. 2015;42:353-62.

Magnadóttir B. Innate immunity of fish (overview). Fish Shellfish Immunol. 2006;20:137-51.

McCormick SD. Effects of growth hormone and insulin-like growth factor I on salinity tolerance and gill $\mathrm{Na}^{+}, \mathrm{K}^{+}$-ATPase in Atlantic salmon (Salmo salar): interaction with cortisol. Gen Comp Endocrinol. 1996;101:3-11.

Merimee TJ, Laron Z. Growth hormone, IGF-I and growth: new views of old concepts. London, UK: Freund; 1996.

Metón I, Caseras A, Cantó E, Fernández F, Baanante IV. Liver insulin-like growth factor-I mRNA is not affected by diet composition or ration size but shows diurnal variations in regularly-fed gilthead sea bream (Sparus aurata). J Nutr. 2000;130:757-60.

Meyers SP. Utilization of shrimp processing wastes. Infofish Mark Dig. 1986;4:18-9.

Moriyama S, Ayson FG, Kawauchi H. Growth regulation by insulin-like growth factor-I in fish. Biosci Biotechnol Biochem. 2000;64:1553-62.

Nii Y, Fukuta K, Yoshimoto R, Sakai K, Ogawa T. Determination of antihypertensive peptides from an izumi shrimp hydrolysate. Biosci Biotechnol Biochem. 2008;72:861-4.

Nwanna LC. Nutritional value and digestibility of fermented shrimp head waste meal by african catfish Clarias gariepinus. Pakistan J Nutr. 2003;2:339-45.

Olsen RE, Suontama J, Langmyhr E, Mundheim H, Ringø E, Melle W, et al. The replacement of fish meal with Antarctic krill, Euphausia superba in diets for Atlantic salmon, Salmo salar. Aquac Nutr. 2006;12:280-90.
Pfaffl MW. A new mathematical model for relative quantification in real-time RT-PCR. Nucleic Acids Res. 2001;29:e45.

Plascencia-Jatomea M, Olvera-Novoa MA, Arredondo-Figueroa JL, Hall GM, Shirai K. Feasibility of fishmeal replacement by shrimp head silage protein hydrolysate in Nile tilapia (Oreochromis niloticus L) diets. J Sci Food Agric. 2002;82:753-9.

Pohlenz C, Buentello A, Criscitiello MF, Mwangi W, Smith R, Gatlin III DM. Synergies between vaccination and dietary arginine and glutamine supplementation improve the immune response of channel catfish against Edwardsiella ictaluri. Fish Shellfish Immunol. 2012;33:543-51.

Quade MJ, Roth JA. A rapid, direct assay to measure degranulation of bovine neutrophil primary granules. Vet Immunol Immunopathol. 1997;58:239-48.

Rajanbabu V, Chen JY. Applications of antimicrobial peptides from fish and perspectives for the future. Peptides. 2011;32:415-20.

Ringø E, Zhou Z, Olsen RE, Song SK. Use of chitin and krill in aquaculture - the effect on gut microbiota and the immune system: a review. Aquac Nutr. 2012;18:117-31.

Rosenlund G, Torstensen BE, Stubhaug I, Usman N, Sissener $\mathrm{NH}$. Atlantic salmon require long-chain n-3 fatty acids for optimal growth throughout the seawater period. J Nutr Sci. $2016 ; 5:$ e19.

Saleh R, Burri L, Benitez-Santana T, Turkmen S, Castro P, Izquierdo M. Dietary krill meal inclusion contributes to better growth performance of gilthead seabream juveniles. Aquac Res. 2018;49:3289-95.

Shahidi F, Synowiecki J. Isolation and characterization of nutrients and value-added products from snow crab (Chinoecetes opilio) and shrimp (Pandalus borealis) processing discards. J Agric Food Chem. 1991;39:1527-32.

Shamblott MJ, Cheng CM, Bolt D, Chen TT. Appearance of insulin-like growth factor mRNA in the liver and pyloric ceca of a teleost in response to exogenous growth hormone. Proc Natl Acad Sci USA. 1995;92:6943-6.

Shimizu C, Ibrahim A, Tokoro T, Shirakawa Y. Feeding stimulation in sea bream, Pagrus major, fed diets supplemented with Antarctic krill meals. Aquaculture. 1990;89:43-53.

Siddik MAB, Howieson J, Fotedar R. Beneficial effects of tuna hydrolysate in poultry by-product meal diets on growth, immune response, intestinal health and disease resistance to Vibrio harveyi in juvenile barramundi, Lates calcarifer. Fish Shellfish Immunol. 2019;89:61-70.

Silva-Carrillo Y, Hernández C, Hardy RW, González-Rodríguez 
B, Castillo-Vargasmachuca S. The effect of substituting fish meal with soybean meal on growth, feed efficiency, body composition and blood chemistry in juvenile spotted rose snapper Lutjanus guttatus (Steindachner, 1869). Aquaculture. 2012;364:180-5.

Takagi S, Shimeno S, Hosokawa H, Ukawa M. Effect of lysine and methionine supplementation to a soy protein concentrate diet for red sea bream Pagrus major. Fish Sci. 2001;67:1088-96.

Takii K, Konishi K, Ukawa M, Nakamura M, Kumai H. Influence of feeding rates on digestion and energy flow in tiger puffer and red sea bream. Fish Sci. 1997;63:355-60.

Teshima SI, Koshio S, Ishikawa M, Alam MS, Hernandez LHH. Effects of protein and lipid sources on the growth and survival of red sea bream Pagrus major and Japanese flounder Paralichthys olivaceus receiving micro-bound diets during larval and early juvenile stage. Aquac Nutr. 2004;10:279-87.

Tharaka K, Benitez-Santana T, Gunathilaka BE, Kim MG, Lee C, Shin J, et al. Evaluation of Antarctic krill (Euphausia superba) meal supplementation in diets for olive flounder (Paralichthys olivaceus ). Aquac Res. 2020;51:2291-302.

Tibbetts SM, Milley JE, Lall SP. Apparent protein and energy digestibility of common and alternative feed ingredients by Atlantic cod, Gadus morhua (Linnaeus, 1758). Aquaculture. 2006;261:1314-27.

Tilseth S, Høstmark Ø. New method for making krill meal. United States patent US20090061067. 2009 Mar 5.

Valero Y, Saraiva-Fraga M, Costas B, Guardiola FA. Antimicrobial peptides from fish: beyond the fight against pathogens. Rev Aquac. 2020;12:224-53.

Wei Y, Shen H, Xu W, Pan Y, Chen J, Zhang W, Mai K. Replacement of dietary fishmeal by Antarctic krill meal on growth performance, intestinal morphology, body composition and organoleptic quality of large yellow croaker Larimichthys crocea. Aquaculture 2019;512:734281.

Xie D, Gong M, Wei W, Jin J, Wang X, Wang X. Antarctic krill (Euphausia superba) oil: a comprehensive review of chemical composition, extraction technologies, health benefits, andApplications. Compr Rev Food Sci Food Saf. 2019;18:514-34.

Xie JJ, Chen X, Liu YJ, Tian LX, Xie SW, Niu J. Effects of dietary astaxanthin on growth performance, hepatic antioxidative activity, hsp70, and HIF-1a gene expression of juvenile golden pompano (Trachinotus ovatus). Isr J Aquac. Bamidgeh. 2017;69:12.
Yamamoto T, Akimoto A, Kishi S, Unuma T, Akiyama T. Apparent and true availabilities of amino acids from several protein sources for fingerling rainbow trout, common carp, and red sea bream. Fish Sci. 1998;64:448-58.

Yan J, Chang Q, Chen S, Wang Z, Lu B, Liu C. Effect of dietary antarctic krill meal on growth performance, muscle proximate composition, and antioxidative capacity of juvenile spotted halibut, Verasper variegatus. J World Aquac Soc. 2018;49:761-69.

Yoshitomi B, Aoki M, Oshima SI, Hata K. Evaluation of krill (Euphausia superba) meal as a partial replacement for fish meal in rainbow trout (Oncorhynchus mykiss) diets. Aquaculture. 2006;261:440-6.

Zheng K, Liang M, Yao H, Wang J, Chang Q. Effect of dietary fish protein hydrolysate on growth, feed utilization and IGF-I levels of Japanese flounder (Paralichthys olivaceus). Aquac Nutr. 2012;18:297-303. 